\title{
Monetary Policy and Exchange Rate Dynamics: Does the Turkish Lira Overshoot?
}

\section{Para Politikası ve Döviz Kuru Dinamikleri: Türk Lirasında Sıçrama Etkisi Geçerli Mi?}

\author{
Bilge Kağan Özdemir ${ }^{1} \oplus$, Ilyas Şıklar ${ }^{2} \odot$
}

\begin{abstract}
This study aims to identify exogenous shocks in monetary policy and to investigate the impact of these shocks on the exchange rate in the Turkish economy using a VAR model including structural restrictions, referred to as structural VAR (SVAR) model. The empirical model used in the study was developed based on the monetary approach to exchange rate determination and was estimated using monthly data for the period between January 2003 and October 2019. Contrary to past studies conducted for Turkey, this study uses European Union data instead of U.S. data to represent foreign variables. The impulse response functions and variance decompositions obtained as a result of the SVAR model confirm the existence of a strong and almost instant overshooting effect on the Turkish economy for the period in question.
\end{abstract}

Keywords

SVAR, Monetary Policy Shocks, Exchange Rate, Overshooting

Öz

Bu çalışma, para politikasındaki dışsal şokları tanımlamayı ve yapısal VAR (SVAR) modeli olarak adlandırılan yapısal kısıtlar içeren bir VAR modeli kullanarak, bu şokların Türkiye ekonomisindeki döviz kuru üzerindeki etkisini araştırmayı amaçlamaktadır. Çalışmada kullanılan ampirik model, döviz kurunun belirlenmesinde parasal yaklaşım çerçevesinde geliştirilmiştir ve Ocak 2003 ile Ekim 2019 arasındaki döneme ilişkin aylık veriler kullanılarak tahmin edilmiştir. Türkiye için yapılan geçmiş çalışmaların aksine, bu çalışma yabancı değişkenleri temsil etmek için ABD verileri yerine Avrupa Birliği verilerini kullanmaktadır. SVAR modelinin tahmini sonucu elde edilen etki-tepki ve varyans ayrıştırması fonksiyonları, analiz sürecinde Türkiye ekonomisinde güçlü ve neredeyse eşanlı bir döviz kuru sıçrama etkisinin varlığını doğrular niteliktedir.

\section{Anahtar Kelimeler}

SVAR, Para Politikası Şokları, Döviz Kuru, Sıçrama

1 Corresponding author: Bilge Kağan Özdemir (Assoc. Prof. Dr.), Anadolu University, Faculty of Economics and Administrative Sciences, Department of Economics, Eskişehir, Turkey. E-mail: bilgeko@anadolu.edu.tr ORCID: 0000-0002-8716-9305

2 Illyas Şıklar (Prof. Dr.), Anadolu University, Faculty of Economics and Administrative Sciences, Department of Economics, Eskişehir, Turkey. E-mail: isiklar@anadolu.edu.tr ORCID: 0000-0003-3181-2522

Attf: Ozdemir, B. K., \& Siklar, I. (2020). Monetary Policy and Exchange Rate Dynamics: Does the Turkish Lira Overshoot? SiYASAL: Journal of Political Sciences, 29(2), 271-289. http://doi.org/10.26650/siyasal.2020.29.2.0002 


\section{Monetary Policy and Exchange Rate Dynamics: Does the Turkish Lira Overshoot?}

The Bretton Woods agreement was adopted in the post-World War II period as a result of negotiations with delegates from 44 countries under the leadership of the countries that won the war. With the acceptance of this agreement in 1946, the foundations of a new international monetary system were laid, and this system continued until 1973 (Krugman et al. 2012). In this system, international reserves were based on gold, and the only currency that could be converted into gold was specified as being American dollars. In other words, in this system, the US dollar was set as the "reserve currency" and the currency of each member country was determined either in terms of gold or in terms of the dollar which was convertible into gold. Due to the loss of trust in the US Dollar, the agreement ended in 1971 with a unilateral decision taken by the US government against the demands of the United Kingdom and France to convert the dollar reserves to gold (Iwami, 1995; Bordeaux and Eichengreen, 2008; Yanar 2008). In the post-Bretton Woods period, there have been radical changes in the relations between states and markets. As a result of factors that emerged in the last period of the Bretton Woods system such as high inflation, an unreliable exchange rate system, and trade instability, developed countries adopted the floating exchange rate regime after 1973. With the parity of the currencies of the country currencies left to fluctuate in the free market environment, the risks of investors increased and the markets were subject to much fluctuation compared to the period of the Bretton Woods system (Alp, 2000; Garcia-Herrero et al. 2008). Studies on the role of monetary models in determining the exchange rate are typically based on the 1970s, when a flexible exchange rate system became widespread in economies after the Bretton Woods Agreement was abandoned. (Frenkel, 1976; Dornbusch, 1976; Frankel 1979; Dornbusch and Fisher, 1980). Although many different models have been built up since the 1970s, there is still debate among economists about which model best describes the behavior of the exchange rate.

The sticky-price monetary model of exchange rate (Dornbusch, 1976), also regarded as the study of the emergence of modern international economics (see Rogoff, 2002), has a special place in the monetary approach of exchange rate. The model is based on the basic assumption that adjustment in the commodity market is slower than the asset market. Accordingly, although the commodity market prices and labor market wages, which are set on a sticky assumption, are slowly adjusted against shocks such as changes in money supply, the exchange rate exhibits a flexible adjustment. In other words, while exchange rates react immediately in response to monetary shocks, commodity markets are moving towards long-term equilibrium with price adjustment. Consequently, exchange rate changes in this case are not consistent with the movement in prices and may deviate from the Purchasing Power Parity (PPP) in the long run.

According to this model, as a result of a monetary shock, such as an increase in money supply, the exchange rate will first rise above its long-term level and over time move towards the long-term equilibrium value through price adjustment in commodity markets.

Following Dornbusch's (1976) study of great interest, several further studies were conducted to test the validity of Dornbusch's assumptions and results. Eichenbaum and Evans (1995)'s pioneering work is considered to be the beginning of this and the result of these studies have led to two main conclusions. First, empirical evidence is consistent with the result of exchange rate overshooting. For example, Frankel (1979); Driskill 
(1981); Rogoff (2002); Kim and Roubini, (2000); Faust and Rogers, (2003); Bjornland, (2009); Kim, Moon, and Velasco (2017) achieved results consistent with the overshooting model. However, Eichenbaum and Evans, (1995); Bahmani-Oskooee and Kara, (2000); Scholl and Uhlig, (2008) found evidence of a delayed version of the overshooting model.

This study aims to analyze the impact of monetary shocks on the exchange rate in the Turkish economy and covers the period between January 2003 and October 2019. The 2001 crisis was a turning point for the Turkish Economy. After the economic crisis in 2001, Turkey adopted the floating exchange rate regime and this exchange rate regime continued to be used throughout the period covered by this study. Another important development in the Turkish economy in the post-crisis era was the adaptation of the inflation targeting regime as of 2002 and inflation targeting regime continued to be implemented during the period covered by our study. In the period that continued until 2013 after the 2001 crisis, the nominal value of the Turkish Lira against the US Dollar and the Euro remained stable due to factors such as the improvement in the Turkish economy and political stability. Even in the period between 2008 and 2011, when the effects of the global crisis on the world economy were keenly felt, the stable course of the value of the Turkish Lira remained unchanged. However, a more rapid increase in foreign exchange in the Turkish economy was observed between the years 2014 and 2016 (Kartal et al. 2018; TBB 2019).

At the beginning of 2017, the Turkish Lira experienced significant depreciation and subsequently was partially appreciated. Following this, the relatively stable course in the value of the Turkish Lira continued until the third quarter of 2018. The sharp and rapid decline in demand caused by the slowdown in international capital inflows in the third quarter of 2018 led to a significant depreciation in the Turkish Lira and as a result, inflation expectations worsened and foreign exchange reserves decreased. The central bank raised short-term interest rates in order to defend the Turkish Lira and reduce volatility in money markets. The volatility in exchange rates continued in the first quarter of 2019 and followed a relatively stable course in the following period. (TBB 2019; CBRT, 2019a; 2019b).

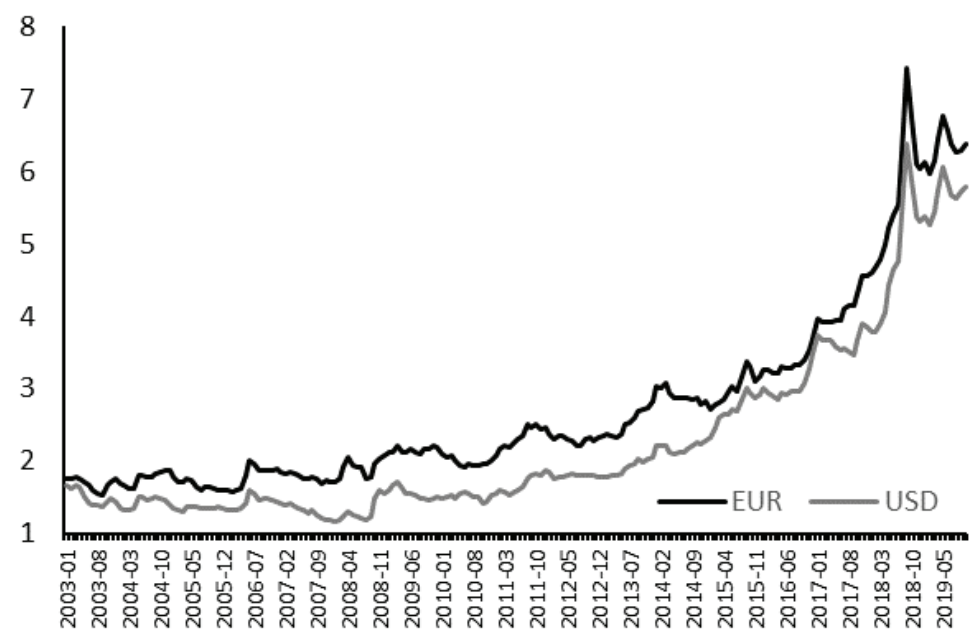

Figure 1. USD/TRY and EUR/TRY Exchange Rates for the Full Sample 
In this study, a VAR model including structural restrictions, referred to as structural VAR (SVAR) model, will be used in order to identify exogenous shocks in monetary policy and to investigate the impact of these shocks on the exchange rate in the Turkish economy. Since almost 70\% of Turkey's foreign trade is realized with European Union countries, this study uses the European Union data instead of the U.S. date to represent foreign variables. It also uses EUR/TRY exchange rate instead of USD/TRY exchange rate to represent the nominal foreign exchange rate. Furthermore, this paper also aims to explain the causes of the observed exchange rate volatility which has been seen in the Turkish economy in recent years.

The rest of the paper is organized as follows. Section 2 provides a brief review of theoretical and empirical literature, Section 3 explains the model and describes the estimation methodology and the data used in the study, Section 4 presents and discusses the empirical results, and Section 5 concludes the paper.

\section{A Brief Review of Literature}

As noted above, the main theoretical contribution in this research area is the Dornbusch (1976) study, which yields the well-known overshooting result. In standard overshooting models, the exchange rate rapidly appreciates in response to the interest rate shock, and then depreciates over time to meet the uncovered interest rate parity (UIP) condition (Dornbusch 1976; Frankel, 1979).

In the empirical literature, a large number of studies have tested the validity of Dornbusch's assumptions and results. In one of the early studies, Driskil (1981) used a reduced-form exchange-rate equation for Switzerland and U.S. data for the period between 1973 and 1979. This study found a short-run exchange-rate overshooting as a response to a monetary shock. Eichenbaum and Evans (1995) analyzed the effects of US monetary policy shocks on five different exchange rates for the period 1974-1990 in a Choleskytype causal order using VAR framework. The emphasis on "delayed overshooting puzzle" was made for the first time in this study, which is different from the standard theory in that the exchange rate is continuously appreciated for a certain period of time before it is ultimately depreciated, rather than the immediate adjustment of exchange rates. This article found that there were significant and persistent deviations from the UIP as a result of the increase in US interest rates, and that the results of the UIP due to the monetary policy shock were not reached in the empirical results. Another important conclusion of this pioneering study is that it provides evidence that the deterioration in monetary variables constitutes a large part of exchange rate movements.

Grilli and Roubini (1996) examined the monetary policies of G-7 countries for the period 1974-1991 with the unrestricted VAR approach. The results of this study show strong evidence of an exchange rate puzzle, namely contrary to the general prediction of exchange rate models, and following a monetary contraction, the German mark, the French franc, the Italian lira and The Canadian Dollar depreciated against the US dollar.

Cushman and Zha (1997) found instant overshooting in their study of monetary policies in Canada. This study also argued that contradictions, such as exchange rate or interest rate puzzles, emerge because of the modeling of monetary policy with a recursive identification approach. Accordingly, while the recursive identification approach yields relatively 
consistent results in modeling the US monetary economy, it is unlikely to be applicable to smaller and open economies. Central banks in a small and open economy are likely to react immediately to foreign variables, and therefore, assuming that interest rate changes are independent, may lead to inconsistent results. In this study, which uses the structural VAR model (as opposed to the recursive approach applied in Eichenbaum and Evans (1995)) to eliminate these problems, no exchange rate or interest rate puzzle emerged.

Similarly, Kim \& Roubini (2000) adopted a structural approach to the identification of monetary policy shocks. The study finds that monetary policy shocks were identified as a major cause (almost $60 \%$ ) of the exchange rate fluctuations in Canada. Another important result obtained from the paper is that the structural approach adopted is successful in identifying monetary policy shocks and in solving riddles and abnormalities related to the effects of monetary policy shocks. The authors also argue that there is no evidence of the price puzzle, which is briefly referred to as the price level being different than expected after a contractionary monetary policy shock. Evidence of an 'exchange rate puzzle', which analyzes the value-adding effect of a positive innovation in interest rates on the country's currency, could not be reached. Finally, little evidence was found to support forward discount bias puzzle and delayed overshooting.

Faust and Rogers (2003), used an inference procedure that allows for the relaxing of dubious identifying assumptions, including the effect of inflation and interest rate constraints on impulse responses. Their findings were consistent with the overshooting hypothesis, namely that the highest exchange rate response to monetary policy shocks may either be delayed or happen almost immediately. However, in any otherwise plausible identification, monetary policy shocks lead to large uncovered interest rate parity deviations, which means that excessive attraction cannot be driven by Dornbusch's hypothesis.

Bjornland's study in 2009 of four small open economies, namely Australia, Canada, New Zealand and Sweden, which implement the floating exchange rate regime, revealed that a monetary policy shock had a significant impact on the real exchange rate. In this study, the slow return of the exchange rate to the baseline occurs within 1-2 quarters. While the results obtained in this study are consistent with the overshooting hypothesis, they are also consistent with uncovered interest rate parity, with a few exceptions.

In the study conducted by Bhadury and Taniya (2015), the Dornbusch model was revised for the Australian, Canadian, New Zealand and Swedish economies by adding real money demand to Bjorland's (2009) model. In the SVAR model used in this study, restrictions are included to determine the supply and demand of money on the basis of the assumption of neutrality of money in the long run, while in the short term there is no restriction on the interaction between monetary policy and exchange rate. The finding showed that the monetary policy contraction caused the exchange rate to be overshot, as stated in the Dornbusch's hypothesis.

Using a method of sign restrictions, Kim et al. (2017) found that, in support of Dornbusch's overshooting hypothesis, the UIP parity failed to hold in the 1980s, but tended to hold elsewhere. This study also showed that the monetary policy regime itself is central to explaining exchange rate fluctuations attributable to monetary policy shocks. As a result of their studies on the United Kingdom, Canada, Sweden, and Australia in 
2018, Kim \& Lim found that contractionary monetary policy shocks caused the exchange rate to gain significant value. They also found that the delay in overshooting is up to six months, and that, although in some cases significant on short horizons, the deviation from the uncovered interest parity condition was relatively small.

Studies that test the overshooting hypothesis of the exchange rate in developing economies have increased, particularly in the post-2008 crisis period (Duasa, 2009; Haghighat and Shojaei, 2014; Barnet et al., 2016; Güneş and Karul, 2016; Capistran et al., 2017). Nieh and Wang (2005) analyzed the Taiwanese economy for the period between 1986 and 2003. Empirical results obtained in this study using Johansen cointegration and ARDL bounds test support the presence of overshooting. In another study dealing with Asian economies, Pratomo (2005) analyzed whether the Indonesian Rupiah was overshot during the 1998 Asian Crisis. The study showed that the economic crisis in 1998 caused the exchange rate to jump, and after the crisis the structural change in the exchange rate regime led to the transition from the free fluctuation system to the exchange rate regime.

Haghighat and Shojaei (2014) conducted the ARDL test for 2002-2011 period and explored the hypothesis overshooting for Iran. This study states that there are empirical findings supporting the overshooting theory for Iran. Barnet et al. (2016) revised the questions about monetary policy, delayed exchange rate overshooting, inflationary puzzles and monetary transmission mechanism for the Indian economy. As a result, they concluded that the inclusion of Divisia monetary aggregates in an open economy model helped to explain the exchange rate response to central bank interest rate shocks, and this also helped in the solution of paradoxes struggling with exchange rate fluctuations such as price puzzle and exchange rate puzzle. In their study on Mexico, Capistran et al. (2017) tested Dornbusch's hypothesis of exchange rate overshooting using a structural cointegrated VAR model that clearly takes into account the existence of longterm theoretical relationships on macroeconomic variables. This study concluded that exchange rate response to monetary policy shocks is consistent with Dornbusch's model.

Studies testing the hypothesis of exchange rate overshooting for the Turkish economy are rather limited. Bahmani-Oskooee and Kara (2000) investigated the depreciation of the Turkish Lira in response to the sudden increase in money supply for the period between January 1987 and December 1998. In this study, cointegration and error correction modeling as adopted and it was demonstrated that the Turkish Lira followed a path summarized by monetary approach in exchange rate determination. Another result of this study was that the Turkish Lira overshot not only in the short term but also in the long term in response to the rapid increase in the money supply. In other words, the spread of the exchange rate might be a long-term phenomenon. Güneş and Karul (2016) showed that the short-term exchange rate equilibrium value exceeded the long-term equilibrium value in line with the exchange rate overshooting model, although the results obtained using the ARDL model for the period between 2000 and 2014 were not statistically significant.

\section{Model and the Estimation Methodology}

Monetary approach to exchange rate determination is developed with reference to the definition of exchange rate. Because an exchange rate is the comparative price of domestic and foreign currencies, factors determining this value are the relative supply of 
and demand for these currencies. Therefore, models developed by Dornbusch (1980) and Frankel (1979) start analyzing by considering functions that essentially explain the real money demand. They define domestic and foreign demand for money as:

Domestic:

$$
\begin{aligned}
& (m-p)=\beta(y)-\delta(i)(1) \\
& p=m-\beta(y)+\delta(i)(2)
\end{aligned}
$$

Foreign:

$$
\begin{aligned}
& \left(m^{*}-p^{*}\right)=\beta\left(y^{*}\right)-\delta\left(i^{*}\right)(3) \\
& p^{*}=m^{*}-\beta\left(y^{*}\right)+\delta\left(i^{*}\right)(4)
\end{aligned}
$$

If we combine equations (2) and (4) and assume that purchasing power parity operates in the long run, we get:

$$
e=p-p^{*}=\left(m-m^{*}\right)-\beta\left(y-y^{*}\right)+\delta\left(i-i^{*}\right)(5)
$$

Here $m$ is the monetary aggregate, $p$ is the price level, $y$ is the real income as a scale variable, $i$ is the interest rate and $e$ is the current nominal exchange rate. In the above equations * superscript stands for the foreign counterparts of the related variables. Throughout this study lower case letters represent the logarithmic levels of the indicated time series (except for the interest rate and inflation rate). Depending on two additional assumptions Frankel's model differs to some extent from equations (1) and (3) above. At the outset, efficient markets hypothesis, through which fixed income securities in various countries are accepted as perfect substitutes, is incorporated in the interest rate parity condition and then the expected change in the foreign exchange rate is defined as:

$$
d=i-i^{*}(6)
$$

The assumption that states the anticipated change in exchange rate is primarily determined by the difference between current market and equilibrium rates and inflation differential between domestic and foreign inflation rates is included to the model such that:

$$
d=-\theta(e-\bar{e})+\pi-\pi^{*}(7)
$$

where $\pi$ and $\pi^{*}$ are the expected long run inflation rates for home and abroad, respectively. The bar over any variable represents the long run equilibrium value of the related variable. Combining (6) and (7) yields:

$$
e-\bar{e}=-\frac{1}{\theta}\left[(i-\pi)-\left(i^{*}-\pi^{*}\right)\right](8)
$$

Frankel (1979) insists that the term in brackets is the real interest rate differential between domestic and foreign countries. Furthermore, stating that in the long run $e=\bar{e}$ and $i-i^{*}=\pi-\pi^{*}$. Frankel (1979) includes the equation (5) considered by Dornbusch (1980) as follows:

$$
\bar{e}=\bar{p}-\bar{p}^{*}=\bar{m}-\bar{m}^{*}-\beta\left(\bar{y}-\bar{y}^{*}\right)+\delta\left(\pi-\bar{\pi}^{*}\right)
$$

If we assume that current levels of money stock and income also represent equilibrium values, substituting (9) into (8) yields the following spot exchange rate equation: 


$$
e=m-m^{*}-\beta\left(y-y^{*}\right)-\frac{1}{\theta}\left(i-i^{*}\right)+\left(\frac{1}{\theta}+\delta\right)\left(\pi-\pi^{*}\right)(10)
$$

Defining $\boldsymbol{\alpha}=\left(-\frac{1}{\theta}\right)$ and $\varphi=\left(\frac{1}{\theta}+\delta\right)$ and including an error term $(\xi)$ generates

$$
e=m-m^{*}-\beta\left(y-y^{*}\right)+\alpha\left(i-i^{*}\right)+\varphi\left(\pi-\pi^{*}\right)+\xi(11)
$$

Theoretically it is expected that $\alpha<0, \varphi>0$ and $|\varphi|>|\alpha|$. In fact, this difference created by Frankel (1979) in the model brings together the Keynesian sticky price assumption and Monetarist secular inflationary bias assumption. In Frankel's model, exchange rate is adversely related with nominal interest rate differential contrary to a positive relationship in Dornbusch's original model. Dornbusch states that a relatively high domestic interest rate decreases the real money balances and increases the price level and, hence, causes a depreciation in the value of domestic currency. This postulation refers to a positive sign for the interest rate coefficient. However, Frankel (1979) postulates that, in the long run, expected inflation differential positively affects the exchange rate. The fundamental difference between Dornbusch and Frankel models, therefore, is the difference of the expected sign of the nominal interest rate coefficient.

In the light of the above explanations, the model to be discussed in this study is determined as follows:

$$
e=f\left[\left(m-m^{*}\right),\left(y-y^{*}\right),\left(i-i^{*}\right),\left(\pi-\pi^{*}\right)\right]
$$

Within the framework of this functional representation, the expected relationships between the variables in the model and the exchange rate are as follows:

$$
\begin{gathered}
\left(m-m^{*}\right) \rightarrow(+) \\
\left(y-y^{*}\right) \rightarrow(-) \\
\left(i-i^{*}\right) \rightarrow(-/+) \\
\left(\pi-\pi^{*}\right) \rightarrow(+)
\end{gathered}
$$

\section{Estimation Methodology}

In this study, VAR model including structural restrictions will be used in order to identify external shocks in monetary policy and to investigate the impact of these shocks on exchange rate. In the literature, such VAR models are referred to as structural VAR (SVAR) models. Previous studies examining the effects of monetary policy have suggested that it is quiet convenient to use structural VAR models, as they are very practical for the identification of exogenous monetary policy shocks (Chusman and Zha,1997; Kim and Roubini, 2000; Capistrán et al, 2017). Within the framework of this methodology, the appropriate constraints are imposed on the model and thus some contradictions in the literature (like liquidity puzzle and price puzzle) can be eliminated. It is generally expected that an exogenous monetary contraction (expansion) decreases (increases) monetary aggregates and prices while it creates an upward (downward) pressure on interest rate. Yet, in a model that employs unanticipated changes in broadly defined money as the 
contractionary (expansionary) monetary policy shock, both money supply and interest rate decrease (increase). This situation is called a liquidity puzzle. However, in a model that employs unanticipated positive (negative) interest changes as the monetary policy shock, both interest rates and prices increase (decrease). This means that the model confronts the price puzzle. The existence of these puzzles indicates that monetary policy shocks are not appropriately defined (Christiano et al., 1999; Kim, 2013). In order to solve these types of puzzles, imposing some structural restrictions on impulse - response functions in the identification process of monetary policy shocks is considered to be a convenient methodology. This is because the response functions indicating the existence of the mentioned puzzles have failed to identify the appropriate monetary policy shock. Therefore, to avoid these puzzles and to ensure that the monetary policy shock is correctly defined, we will use structural restrictions including SVAR methodology which is briefly discussed below.

The reduced form of a standard VAR model can be written as:

$$
Y_{t}=B(L) Y_{t-1}+C(L) X_{t}+\xi_{t} \text {. }
$$

Here $Y$ is endogenous variables vector with $l \times 1$ dimension, $X$ is exogenous variables vector with $m \times 1$ dimension vector of exogenous variables, $\xi$ is the residuals vector with $l \times 1$ dimension having the traditional properties that $E\left(\xi_{t}\right)=0, E\left(\xi_{t}, \xi_{t}^{\prime}\right)=\Xi, B(L)$ and $C(L)$ are $l \times l$ and $l \times m$ dimension polynomial matrices with lag operator $L$. Residual terms of reduced form (components of $\xi_{\mathrm{t}}$ vector) can be explained as a linear combination of structural shocks (components of $\zeta_{\mathrm{t}}$ vector) like

$$
\xi_{t}=A \zeta_{t}(14)
$$

where $A$ and $\zeta_{\mathrm{t}}$ are an $l \times l$ dimension matrix and $l \times 1$ dimension structural shock vector, respectively. Again, the structural shock vector $\zeta_{\mathrm{t}}$ fulfills the traditional properties of $E\left(\zeta_{t}\right)=0$ and $E\left(\zeta_{t}, \zeta_{t}^{\prime}\right)=1$. The recursive identification methodology developed by Sims (1980) heavily depends on obtaining $A$ in the form of a lower triangular matrix through the application of Cholesky decomposition on $\Xi$. Therefore, most of the earlier studies obtain orthogonal structural shocks from the residuals of reduced form to identify $A$ matrix. Recently, Uhlig (2005) obtained structural shocks by enforcing structural constraints on impulse response functions. The above-mentioned paper describes only a single structural shock (monetary policy), that involves the identification of one column (like $a$ ) of lower triangular $A$. In Uhlig's study a reaction vector is defined as follows: “... if matrix A exists, vector $a$ can be called as impulse vector; thus, vector $a$ is treated as a column of matrix $A$ since $A A^{\prime}=\Xi$." Furthermore, Uhlig states that an impulse vector like $a$ can be treated as $a=A \alpha$. Here, $A A^{\prime}=\Xi$ can be defined as the Cholesky decomposition of $\Xi$ where $\alpha$ refers to $l$ dimension unit length vector. In this case, response vector $\left(z_{\mathrm{a}}(p)\right)$ for $a$ is defined as:

$$
z_{a}(p)=\sum_{j=1}^{l} \alpha_{j} z_{j}(p)(15)
$$

Here $z_{\mathrm{j}}(p)$ is the response vector at $p$ length to $j$ th variable of Cholesky decomposition of $\Xi$. Therefore, a range of constraints can be imposed to response vector of $z_{\mathrm{j}}(p)$ at length $p$. 
Within the identification strategy outlined above, we can use short term restrictions on contemporaneous parameters without imposing any restriction on lagged structural parameters. Based on Cholesky decomposition, Sims (1980) suggests the following identification scheme: In the model we will estimate that the ordering starts with the least affected variable and ends with the variable that is considered to be affected by all of the variables. According to this identification rule, since the basic VAR model is

$$
X_{t}^{\prime}=\left[\left(m-m^{*}\right)_{t-j},\left(y-y^{*}\right)_{t-k},\left(i-i^{*}\right)_{t-l},\left(\pi-\pi^{*}\right)_{t-m}, e_{t}\right](16)
$$

for a 5-variable model we will have

$$
A=\left[\begin{array}{ccccc}
1 & 0 & 0 & 0 & 0 \\
\alpha_{21} & 1 & 0 & 0 & 0 \\
\alpha_{31} & \alpha_{32} & 1 & 0 & 0 \\
\alpha_{41} & \alpha_{42} & \alpha_{43} & 1 & 0 \\
\alpha_{51} & \alpha_{52} & \alpha_{53} & \alpha_{54} & 1
\end{array}\right], B=\left[\begin{array}{ccccc}
b_{11} & 0 & 0 & 0 & 0 \\
0 & b_{22} & 0 & 0 & 0 \\
0 & 0 & b_{33} & 0 & 0 \\
0 & 0 & 0 & b_{44} & 0 \\
0 & 0 & 0 & 0 & b_{55}
\end{array}\right] \text { (17) }
$$

Since each of the structural equations is normalized with respect to a specific endogenous variable, diagonal elements of $A$ matrix are equalized to 1 . Furthermore, since each equation has structural shock, $B$ is a diagonal matrix whose off-diagonal elements are zero. Therefore, variance-covariance matrix will have $\frac{n(n+1)}{2}$ parameters to be estimated while $A$ and $B$ matrices produce $\left(n^{2}-n\right)$ and $(n)$ parameters to estimate, respectively. Hence, there should be a minimum $\frac{n(n-1)}{2}$ constraints to be included into the model for identification. If the equation system is over-identified, we can use the Likelihood Ratio (LR) test to verify the reliability of the imposed restrictions (Lutkepohl, 2007).

\section{Identification of the SVAR Model, Data and Estimation Results}

Since the present study accepts Turkey as a small open economy, variables with * superscript are also used as exogenous variables without any lag in the estimation of the VAR model. The small country assumption requires scholars to accept that domestic monetary policy shocks do not have any effect on the differential variables $\left(\alpha_{12}=\alpha_{13}=\right.$ $\alpha_{14}=0$ ). In the model to be estimated, exchange rate changes are allowed to affect prices simultaneously as the existence of a strong currency substitution and pass-through effect from exchange rate to prices (even if it is not complete) in Turkey is known (Ş1klar et al., 2017). Therefore, all the $\alpha_{5 \mathrm{i}}$ parameters are different from zero (for $i=1,2,3,4$ ). Furthermore, following Kim and Roubini (2000), real activity responds to other variables with a lag $\left(\alpha_{21}=\alpha_{23}=\alpha_{24}=0\right)$. As Gali (1992) states, the interest rate is assumed to be the reaction parameter of the monetary authority which, due to informational and decisional lags, cannot respond contemporaneously to changes in other variables. This means $\alpha_{31}=$ $\alpha_{32}=0$. However, to see whether the interest parity condition holds in the short run we imposed $\alpha_{34} \neq 0$. Kim and Roubini (2000) state that real and financial variables respond to prices only with a lag, indicating $\alpha_{41}=\alpha_{42}=\alpha_{43}=0$. With the inclusion of solutions for the puzzles discussed earlier, and imposing the issues mentioned above, the identification of the model is as follows: 


$$
\left[\begin{array}{c}
\zeta_{y-y^{*}} \\
\zeta_{m-m^{*}} \\
\zeta_{\pi-\pi^{*}} \\
\zeta_{i-i^{*}} \\
\zeta_{e}
\end{array}\right]=\left[\begin{array}{ccccc}
1 & 0 & 0 & 0 & \alpha_{15} \\
0 & 1 & 0 & 0 & \alpha_{25} \\
0 & 0 & 1 & \alpha_{34} & \alpha_{35} \\
0 & 0 & 0 & 1 & \alpha_{45} \\
\alpha_{51} & \alpha_{52} & \alpha_{53} & \alpha_{54} & 1
\end{array}\right]\left[\begin{array}{c}
\xi_{y-y^{*}} \\
\xi_{m-m^{*}} \\
\xi_{\pi-\pi^{*}} \\
\xi_{i-i^{*}} \\
\xi_{e}
\end{array}\right]
$$

Almost 70 percent of Turkey's foreign trade is realized with European Union countries, therefore, the most important trade partner for the country is the European Union. Contrary to past studies conducted for Turkey, this study uses European Union data instead of U.S. data to represent foreign variables, and it uses the EUR/TRY exchange rate instead of that of USD/TRY to represent the nominal foreign exchange rate. In the estimation process, we prefer monthly data for a better understanding of the dynamic structure of the model. As discussed earlier in this study, the Turkish economy has experienced a very significant transformation after the financial turmoil of 2001. To avoid the structural break (or breaks) that could have been caused by the financial crisis of 2001, and following the transition to a floating exchange rate regime and to an inflation targeting monetary policy strategy, our estimation period starts in January 2003 and ends with the latest data available (October 2019). While the monthly income time series is proxied with industrial production index, M1 definition of money stock for monetary aggregate, percentage rate of change in consumer price index for inflation, policy rates of central banks (The Central Bank of the Republic of Turkey - CBRT and European Central Bank - ECB) for interest rates are used to represent the related variables in the model. All the Turkish data are obtained from the CBRT's database while the European data are acquired from EUROSTAT database. All domestic and foreign variables, except for interest rates and foreign exchange rates, are seasonally adjusted using Tramo/Seats methodology. Table A1 in the appendix presents more detailed descriptions and sources of the data. Descriptive characteristics and the course of the relevant time series during the analyzing period are presented in Table A2 and Figure A1, respectively, and are found in the Appendix of this study. Unit root properties of the variables can also be found in the same appendix as Table A3.

In order to set the optimal lag length for the SVAR model, we first estimated an unrestricted VAR and obtained various lag selection criteria that are presented in Table A2 in the appendix. While Akaike, Schwarz, Final Prediction Error and Hannan-Quinn information criteria determine the optimal lag length as 2 months, Likelihood Ratio produces a 5-month lag length. As a great majority of the lag length criteria point out a 2-month lag, throughout the estimation process of developed SVAR model, a 2-month lag is used.

Before moving on to the estimation results of the model, it is appropriate to question the statistical validity of the 16 restrictions imposed on the model. Since the model whose restrictions are identified in Equation (18) above is over identified, the value of Likelihood Ratio test with $\chi_{4}^{2} \chi_{4}^{2}$ distribution is LR $=4,3825$ which has a marginal significance level of 0,6251 . Thus, we should accept the null hypothesis that restrictions cannot be rejected, and we conclude that restrictions are reliable in statistical terms. 


\section{Impulse - Response Functions}

Figure 1 displays the structural responses of the endogenous variables in the model to a contractionary monetary policy shock over the next 12 months. All of the responses have the expected signs and the expected course through time (over a 12-month horizon). In the face of contractionary monetary policy shock, while the domestic real income reacts negatively with a 3-month lag, the domestic interest rate responds positively during the first three months but this response gradually burns out within the 12-month period. In line with expectations, this indicates that the liquidity effect is dominant in the very short run but that price and income level effects make themselves felt in the short run. Because of the imposed restriction on the model, the positive response of prices at the beginning of a contractionary monetary policy shock turns negative from the second period and prices adjust throughout the 12-month period.

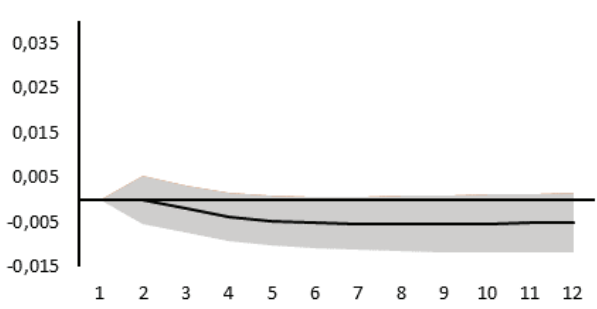

(a) Response of output differential

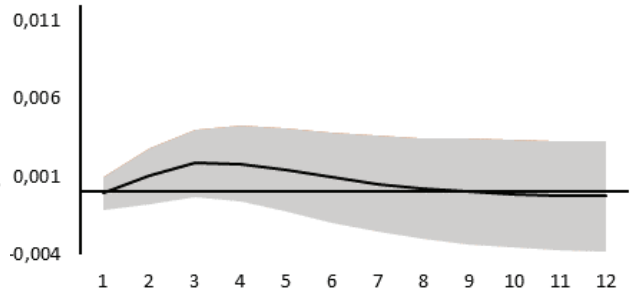

(b) Response of interest rate differential

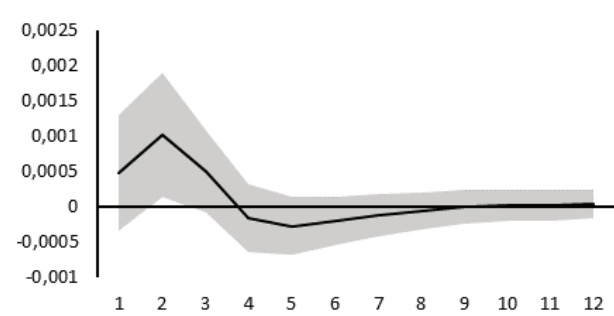

(c) Response of inflation differential

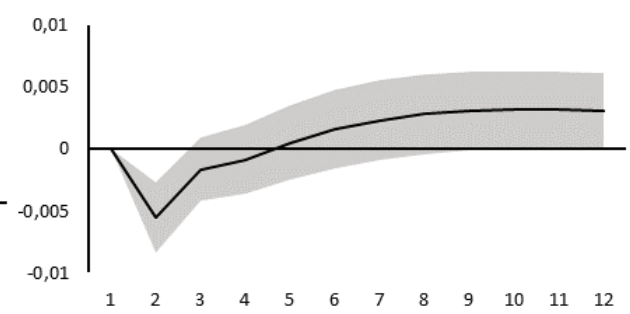

(d) Response of nominal exchange rate

Figure 2. Responses of Endogenous Variables to a Contractionary Monetary Policy Shock

In terms of the subject we are analyzing, the important response is the reaction of exchange rate to a contractionary monetary policy shock and is presented in (d) panel of Figure 2. First of all, for the overshooting effect to be present, the response of the nominal exchange rate should change the sign. Therefore, it is natural that the confidence intervals are stacked on both sides of the horizontal axis. According to the response function in the last panel of the figure, domestic currency reacts against the contractionary monetary policy shock by appreciating during the first two months. However, starting from the third month, this process reverses and domestic currency starts to depreciate. This indicates that the overshooting effect asserted by Dornbusch (1980) is verified by Turkish data through the analyzing period. Although the results we obtained conform with the results of past studies that generally used the US data and USD/TRY exchange rate, our results differ in 
terms of the duration of responses. While the past studies generally obtained a delayed overshooting effect (Bahmani-Oskooee and Kara, 2000; Güneş and Karul, 2016), the SVAR model developed in this study indicates that the exchange rate increases to a higher level than the pre-shock level from the sixth month and reaches the steady state value from the tenth month. Considering the impulse response functions in terms of suggested SVAR model and the period analyzed in this study, the results confirm the existence of a strong and almost instant overshooting effect in the Turkish case.

\section{Variance Decompositions}

A variance decomposition function yields information on the relative contribution of a shock to the variability of the residuals over the specified time horizon. Figure 3 provides variance decompositions of the nominal exchange rate over a 24-month period. As discussed earlier, based on the Cholesky decomposition, the nominal exchange rate was accepted as the most endogenous variable in the SVAR model and located at the furthest end of the variable ordering. In other words, all the other variables in the VAR are allowed to affect the nominal exchange rate. It is quite natural that much of exchange rate forecast errors originate from their own shocks. However, almost 10 percent of forecast error variance of the nominal exchange rate stems from money supply differential along a 24-month period. This clearly indicates the permanent effect of money supply on the nominal exchange rate and reveals the overshooting effect. What is interesting is that, in terms of the relative contribution to forecast error variance of the nominal exchange rate, output differential gains power while interest rate differential loses power when the forecast horizon expands from the short to long run. This situation can be accepted as an indication of the fact that interest rate parity is an important factor in the short run but real factors (like productivity) become important in the long run as stated by the Ballasa - Samuelson approach to exchange rate determination. This, however, is the subject of another research.

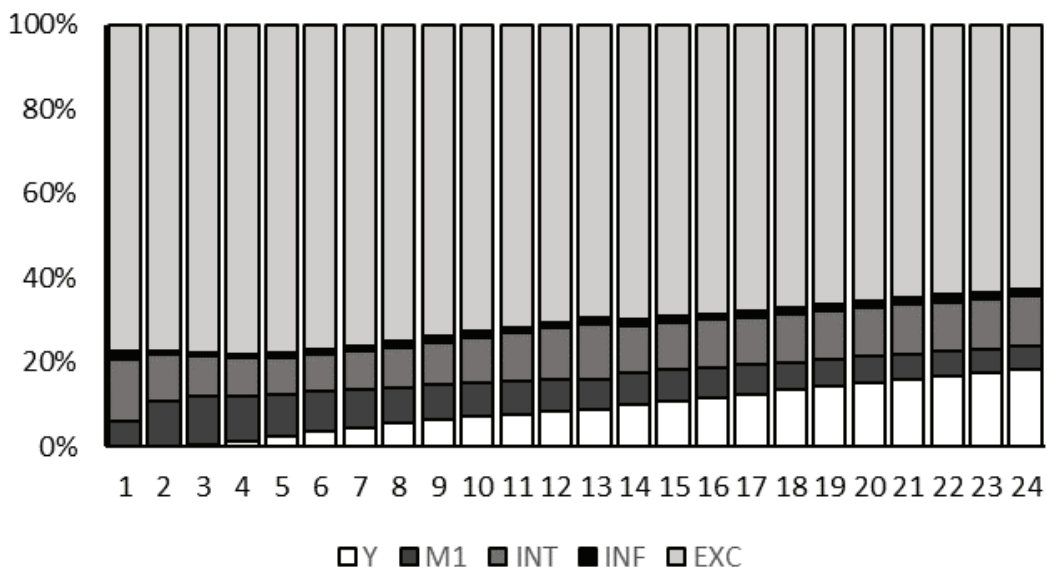

Figure 3. Variance Decompositions of the Nominal Exchange Rate over 24-Month Period

\section{Conclusion}

Although many different models have been built up and afterwards modified, there is no consensus among economists on the model that best explains the behavior of the 
exchange rate. The sticky-price monetary model of exchange rate, also regarded as the study of the emergence of modern international economics, has a special place in the monetary approach to exchange rate. According to this model, as a result of a monetary shock, like an increase in money supply, the exchange rate will first rise above its longterm level and over time move towards the long-term equilibrium value through price adjustment in commodity markets.

Having a strong and long-lasting currency substitution in money markets due to historical high inflation experience, Turkey represents a noteworthy example with its structural reforms after the 2001 financial turmoil. These reforms included decisions like adopting the floating exchange rate regime, inflation targeting monetary policy, central bank independence and government budget discipline. Between 2003 and 2017, the exchange rates increased gradually and steadily due to improvement in the economic structure and political stability observed in the post-crisis period. Even in the period between 2008 and 2011, when the effects of the global crisis were intensely felt on the world economy, the stable course of the value of the Turkish Lira remained unchanged. However, at the beginning of 2017, the Turkish Lira experienced significant depreciation and subsequently partially appreciated. Following this, the relatively stable course in the value of the Turkish Lira continued until the third quarter of 2018. The sharp and rapid decline in demand caused by the slowdown in international capital inflows in the third quarter of 2018 led to a significant depreciation in the Turkish Lira and as a result, inflation expectations worsened and foreign exchange reserves decreased. The volatility in exchange rates continued in the first quarter of 2019 and followed a relatively stable course in the following period. These developments in the value of Turkish Lira made us think of the existence of the overshooting phenomenon in Turkey.

In this study, the VAR model (including structural restrictions) is used in order to identify external shocks in monetary policy and to investigate the impact of these shocks on the exchange rate. In the literature, such VAR models are referred to as structural VAR (SVAR) models. Previous studies examining the effects of monetary policy have suggested that it is suitable to use structural VAR models, as they are very practical in the identification of exogenous monetary policy shocks. Within the framework of this methodology, the appropriate constraints are imposed on the model and thus some contradictions in the literature (like liquidity puzzle and price puzzle) can be eliminated. Based on the identification strategy, we used short term restrictions on contemporaneous parameters without imposing any restriction on lagged structural parameters. Since the equation system is over-identified, we verified the reliability of the imposed restrictions using the Likelihood Ratio $(L R)$ test.

Since the present study accepts Turkey as a small open economy, non-local variables are also used as exogenous variables without any lag in the estimation of the VAR model. Furthermore, in the model, exchange rate changes are allowed to affect prices simultaneously because of the existence of a strong currency substitution and passthrough effect from exchange rate to prices (even if it is not complete) in Turkey. Contrary to past studies conducted for Turkey, this study uses European Union data instead of U.S. data to represent foreign variables, and it uses EUR/TRY exchange rate instead of that of USD/TRY to represent the nominal foreign exchange rate. In the estimation process, we 
prefered monthly data for a better understanding of the dynamic structure of the model for the period between January 2003 and October 2019.

When the economy confronts a contractionary monetary policy shock, while the domestic real income responds negatively with a 3-month lag, the domestic interest rate responds positively during the first three months, but this response gradually burns out within the 12-month period. In line with expectations, this indicates that the liquidity effect is dominant in the very short run but that price and income level effects make themselves felt in the short run. Because of the imposed restriction on the model, the positive response of prices at the beginning of a contractionary monetary policy shock turn to negative from the second period, and prices adjust throughout the 12-month period. Domestic currency reacts against the contractionary monetary policy shock by appreciating during the first two months. However, starting from the third month, this process reverses and domestic currency starts to depreciate. This indicates that the overshooting effect asserted by Dornbusch is verified by Turkish data through the analyzing period. Although the results we obtained conform with the results of past studies that generally used the US data and USD/TRY exchange rate, our results differ in terms of the duration of responses. While past studies generally obtained a delayed overshooting effect, the SVAR model developed in this study indicates that the exchange rate increases to a higher level than the pre-shock level from the sixth month and reaches a steady state value from the tenth month. Considering the impulse response functions and variance decompositions in terms of suggested SVAR model and the period analyzed in this study, our results confirm the existence of a strong and almost instant overshooting effect in the Turkish case.

Peer-review: Externally peer-reviewed.

Conflict of Interest: The authors have no conflict of interest to declare.

Grant Support: The authors declared that this study has received no financial support.

\section{References}

Alp, A. (2000). Finansın uluslararasılaşmast. İstanbul: Yapı Kredi Yayınları.

Backus, D. (1984). Empirical models of the exchange rate: Separating the wheat from the chaff. The Canadian Journal of Economics/Revue Canadienne D'Economique, 17(4), 824-846.

Bahmani-Oskooee, M., \& Kara, O. (2000). Exchange rate overshooting in Turkey. Economics Letters, 68, 89-93.

Barnet, W. A., Bhadury, S. S., \& Ghosh, T. (2016). An SVAR approach to evaluation of monetary policy in India: Solution to the exchange rate puzzles in an open economy. Open Economies Review, 27, 871-893.

Bhadury, S. S., \& Taniya, G. (2015). Reassessing exchange rate overshooting in a monetary framework. Working Paper Indira Gandhi Institute of Development Research (IGIDR).

Bjornland, H. (2009). Monetary policy and exchange rate overshooting: Dornbusch was right after all. Journal of International Economics, 79, 64-77.

Bordo, M., \& Eichengreen, B. (2013). Bretton Woods and the great inflation. In The Great Inflation: The Rebirth of Modern Central Banking (pp. 449-489). University of Chicago Press.

Capistrán C., Chiquiar, D., \& Hernández J. R. (2017). Identifying Dornbusch’s exchange rate overshooting with structural VECs: Evidence from Mexico. Working Papers 2017-11, Banco de México.

CBRT. (2019a). Türkiye Cumhuriyet Merkez Bankası Enflasyon Raporu III.

CBRT. (2019b). Türkiye Cumhuriyet Merkez Bankası Enflasyon Raporu IV.

Christiano, L. J., Eichenbaum, M., \& Evans, C., (1999). Monetary policy shocks: What have we learned and to what end? in Woodfoord, M., and Taylor, J. (Eds) Handbook of Monetary economics, (pp.65-148), North-Holland.

Cushman, D. O., \& Zha, T. (1997). Identifying monetary policy in a small open economy under flexible exchange rates. The Journal of Monetary Economics, 39, 433-448.

Dornbusch, R. (1976). Expectations and exchange rate dynamics. Journal of Political Economy, 84, 1161-1175.

Dornbusch, R. (1980). Exchange rate risk and the macroeconomics of exchange rate determination. NBER Working Paper No. 493. 
Dornbusch, R., \& Fischer, S. (1980). Exchange rates and the current account. The American Economic Review, 70(5), 960-971.

Driskill, R. A. (1981). Exchange rate dynamics: an empirical investigation. Journal of Political Economy, 89, 357-371.

Duasa, J. (2009). Impact of exchange rate shock on prices of imports and exports. International Economic Studies. 34(1), 59-68.

Eichenbaum, M., \& Evans, C. L. (1995). Some empirical evidence on the effects of monetary policy shocks on exchange rates. Quarterly Journal of Economics, 110, 975-1010.

Faust, J., \& Rogers, J. H. (2003). Monetary policy's role in exchange rate behavior. Journal of Monetary Economics, 50, 1403-1424.

Flood, R. P., \& Taylor, M. P. (1996). Exchange rate economics: What is wrong with the conventional macro approach? In: J.A. Frankel, G. Galli, G. \& A. Giovannini (Eds.), Micro structure of foreign exchange markets Chicago, IL: University of Chicago Press.

Frankel, J. (1979). On the mark: A theory of floating exchange rates based on real interest differentials. American Economic Review, 69, 610-622.

Frenkel, J. (1976). A monetary approach to the exchange rate: Doctrinal aspects and empirical evidence. The Scandinavian Journal of Economics, 78(2), 200-224.

Gali, J. (1992). How well does the IS-LM model fit postwar US data? The Quarterly Journal of Economics, 107(2), 709-738.

Garcia-Herrero, A., Vial, J., Escrivá, J. L., \& Nuno, G. (2008). “After Bretton Woods II”,BBVA Working Paper No:0803.

Grilli, V., \& Roubini, R. (1996) Liquidity models in open economies: Theory and empirical evidence. European Economic Review, 40, 847-859.

Güneş, S., \& Karul, Ç. (2016) The Exchange rate overshooting in Turkey. Pamukkale Journal of Euroasian Socieconomic Studies, 3(1), 27-35.

Haghighat, A., \& Shojaei, T. (2014). Exchange rate overshooting in Iran. Academic Journal of Research in Economics and Management, 2(3), 38-43.

Iwami, T. (1995). The Bretton Woods system as a gold exchange standard. In Japan in the International Financial System (pp. 1-35). Palgrave Macmillan, London.

Kartal, M. T., Depren, S. K., \& Depren, Ö. (2018). Türkiye'de döviz kurlarini etkileyen makroekonomik göstergelerin belirlenmesi: Mars yöntemi ile bir inceleme. MANAS Journal of Social Studies, 7(1), $209-229$.

Kim, S. (2005). Monetary policy, foreign exchange policy, and delayed overshooting. Journal of Money, Credit and Banking, 37, 775-782.

Kim, S., (2013). VAR models for macroeconomic policy analysis. in N. Hashimzade and M.A. Thornton (Eds) Handbook of Research Methods and Applications in Empirical Macroeconomics, (pp. 555-574), Edgar Elgar Publishing.

Kim, S., \& Lim, L. (2018). Effects of monetary policy shocks on exchange rate in small open economies. Journal of Macroeconomics, 56, 324-339.

Kim, S. H., Moon, S., \& Velasco, C. (2017). Delayed overshooting: Is it an 80s puzzle? Journal of Political Economy, 125, 1570-1598.

Kim, S., \& Roubini, N. (2000). Exchange rate anomalies in the industrial countries: A solution with a structural VAR approach. Journal of Monetary Economics, 45, 561-586.

Krugman, P. R., Obstfeld, M., \& Melitz, M. J. (2012). "International Economics: Theory and Policy", Pearson Education.

Lütkepohl, H. (2007). General-to-specific or specific-to-general modelling? An opinion on current econometric terminology Journal of Econometrics Volume 136, Issue 1, January 2007, Pages 319-324.

Nieh, C., \& Wang, Y. (2005). ARDL approach to the exchange rate overshooting in Taiwan. Review of Quantative Finance and Accounting, 25, 55-71.

Pratomo, W. A. (2005). Exchange rate of Indonesia: Does Rupiah overshoot?. MPRA Paper No. 7381.

Rogoff, K. (2002). Dornbusch's overshooting model after twenty-five years. Unpublished paper. Washington, DC: IMF Working Paper.

Scholl, A., \& Uhlig, H. (2008). New evidence on the puzzles: Results from agnostic identification on monetary policy and exchange rates. Journal of International Economics, 76, 1-13.

Sims, C. (1980). Macroeconomics and Reality. Econometrica, 48(1), 1-48.

Sims, C.A. (1992). Interpreting the macroeconomic time series facts: the effects of monetary policy. European Economic Review, 36, 975-011.

Şıklar, İ., Kocaman, M., \& Kapkara, S. (2017). Exchange rate pass-through to domestic prices: The Turkish case (2002-2014). Business and Economic Research, 7(2), 202-211.

TBB. (2019). Bankalarımız 2018. Türkiye Bankalar Birliği Yayın No 331.

Yanar, R. (2008). Gelişmekte olan ülkelerde döviz kuru rejimi tercihi ve makro ekonomik performans. Çukurova Üniversitesi, Sosyal Bilimler Enstitüsü, Yayımlanmamış Doktora Tezi. 


\section{Appendices}

Table A1

Description and Sources of the Data

\begin{tabular}{|c|c|c|c|}
\hline Variable & Description & Source & Transformation \\
\hline $\mathrm{m}$ & Narrow (M1) definition of money stock & \multirow{5}{*}{$\begin{array}{l}\text { CBRT - } \\
\text { EDDS }\end{array}$} & $\begin{array}{c}\text { Seasonally adjusted } \\
\text { log level }\end{array}$ \\
\hline $\mathrm{y}$ & Industrial production index $(2015=100)$ & & $\begin{array}{c}\text { Seasonally adjusted } \\
\log \text { level }\end{array}$ \\
\hline $\mathrm{i}$ & Policy rate of CBRT & & Level \\
\hline$\pi$ & $\begin{array}{l}\text { Inflation, percentage change in seasonally adjusted } \\
\text { consumer price index }(2003=100)\end{array}$ & & Level \\
\hline$\Delta \mathrm{e}$ & Percentage change in EURTRY nominal exchange rate & & Level \\
\hline $\mathrm{m}^{*}$ & Narrow (M1) definition of money stock & \multirow{4}{*}{ EUROSTAT } & $\begin{array}{c}\text { Seasonally adjusted } \\
\text { log level }\end{array}$ \\
\hline $\mathrm{y}^{*}$ & Industrial production index $(2015=100)$ & & $\begin{array}{c}\text { Seasonally adjusted } \\
\text { log level }\end{array}$ \\
\hline$i^{*}$ & Repo rate & & Level \\
\hline$\pi^{*}$ & $\begin{array}{c}\text { Inflation, percentage change in seasonally adjusted } \\
\text { consumer price index }(2015=100)\end{array}$ & & Level \\
\hline
\end{tabular}

Note: Variables with * superscript refer to European data while CBRT-EDDS stands for the Central Bank of the Republic of Turkey, Electronic Data Delivery System. Percentage changes have been calculated as the first differences of the logarithms of relevant variables.

Table A2

Descriptive Statistics of the Data

\begin{tabular}{|l|c|c|c|c|c|}
\hline & $\mathbf{m}-\mathbf{m}^{*}$ & $\mathbf{y}-\mathbf{y}^{*}$ & $\mathbf{i}-\mathbf{i}^{*}$ & $\boldsymbol{\pi}-\boldsymbol{\pi}^{*}$ & \multicolumn{1}{|c|}{$\mathbf{e}^{*}$} \\
\hline Mean & 1.665513 & -0.189337 & 0.132106 & 0.006263 & 0.921022 \\
\hline Median & 1.785980 & -0.210105 & 0.113900 & 0.005736 & 0.797507 \\
\hline Maximum & 2.702125 & 0.152201 & 0.451800 & 0.061062 & 2.004179 \\
\hline Minimum & 0.190722 & -0.511419 & 0.052100 & -0.012069 & 0.431782 \\
\hline Std. Dev. & 0.659608 & 0.192861 & 0.075934 & 0.006641 & 0.397892 \\
\hline Skewness & -0.516145 & 0.161763 & 2.235867 & 3.105627 & 1.026930 \\
\hline Kurtosis & 2.347095 & 1.587292 & 8.741796 & 25.78073 & 3.151484 \\
\hline \multicolumn{7}{|l|}{} \\
\hline Jarque-Bera & 12.55690 & 17.67847 & 445.7856 & 4692.641 & 35.69751 \\
\hline Probability & 0.001876 & 0.000145 & 0.000000 & 0.000000 & 0.000000 \\
\hline \multicolumn{7}{|l|}{} \\
\hline Sum & 336.4336 & -38.24609 & 26.68540 & 1.265120 & 186.0465 \\
\hline Sum Sq. Dev. & 87.45169 & 7.476244 & 1.158952 & 0.008864 & 31.82198 \\
\hline Observations & 202 & 202 & 202 & 202 & 202 \\
\hline
\end{tabular}




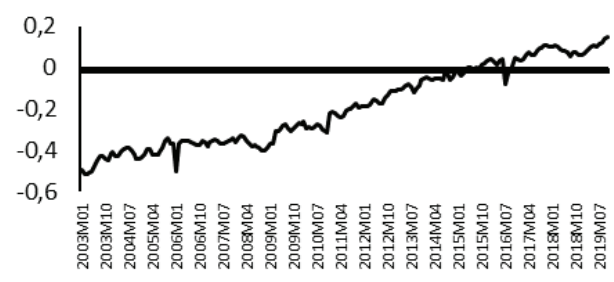

(a) $y-y^{*}$

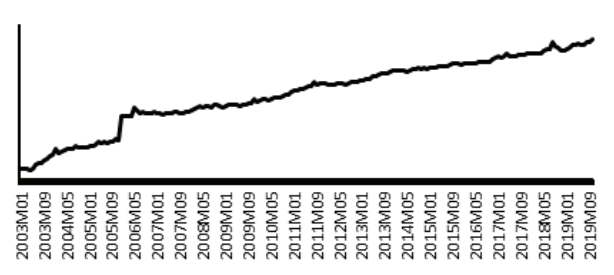

(b) $\mathrm{m}-\mathrm{m}^{*}$

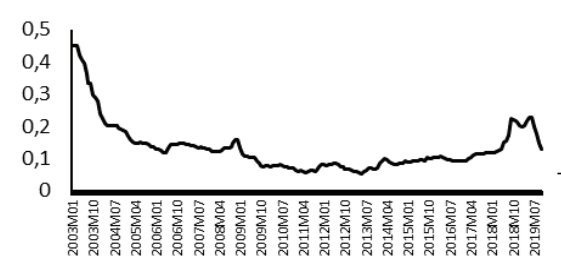

(c) $\mathrm{i}-\mathrm{i}^{*}$

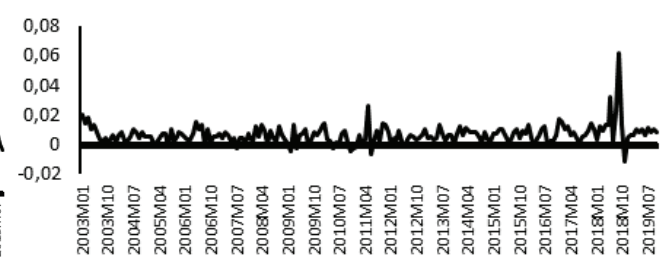

(d) $\pi-\pi^{*}$

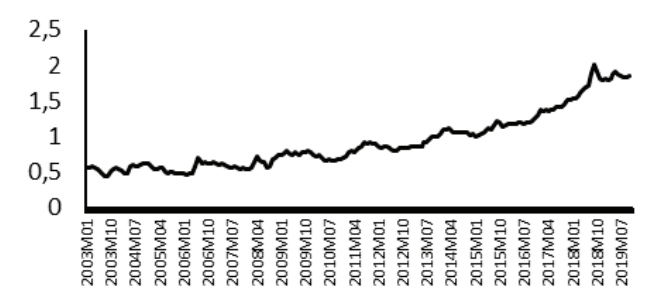

(e) $\mathrm{e}$

Figure A1. Time Series Plots of the Data 
Table A3

Unit Root Test Results

\begin{tabular}{|l|c|c|c|c|c|c|c|c|c|}
\hline \multirow{2}{*}{ Series } & \multicolumn{3}{|c|}{$\begin{array}{c}\text { Augmented } \\
\text { Dickey-Fuller Test }\end{array}$} & \multicolumn{3}{c|}{ Phillips-Peron Test } & \multicolumn{3}{c|}{$\begin{array}{c}\text { Breakpoint } \\
\text { Dickey-Fuller Test }\end{array}$} \\
\cline { 2 - 10 } & Lag $^{* *}$ & Test & Prob. & Band & Test & Prob. & Lag $^{* *}$ & Test & Prob. \\
\hline $\mathrm{m}-\mathrm{m}^{*}$ & 0 & 16.4580 & 0.0000 & 0 & 16.4580 & 0.0000 & 0 & 17.4350 & 0.0000 \\
\hline $\mathrm{y}-\mathrm{y}^{*}$ & 3 & 9.9857 & 0.0000 & 4 & 23.5385 & 0.0000 & 0 & 17.0348 & 0.0000 \\
\hline $\mathrm{i}-\mathrm{i}^{*}$ & 6 & 3.7711 & 0.0038 & 5 & 4.6812 & 0.0001 & 0 & 7.6073 & 0.0000 \\
\hline$\pi-\pi^{*}$ & 2 & 6.3652 & 0.0000 & 4 & 11.1025 & 0.0000 & 0 & 14.5960 & 0.0000 \\
\hline$\Delta \mathrm{e}$ & 1 & 11.0707 & 0.0000 & 8 & 10.3167 & 0.0000 & 1 & 12.0993 & 0.0000 \\
\hline
\end{tabular}

Note: ** Lag length throughout unit root tests is determined by using Akaike Information Criterion. All tests indicate nonexistence of a unit root in the respective series.

Table A4

Determination of Optimal Lag Length

\begin{tabular}{|l|c|c|c|c|c|c|}
\hline Lag & LogL & LR & FPE & AIC & SC & HQ \\
\hline 0 & 1283.187 & NA & $2.20 \mathrm{e}-12$ & -12.65532 & -12.57343 & -12.62219 \\
\hline 1 & 2718.609 & 2785.572 & $1.89 \mathrm{e}-18$ & -26.61989 & -26.12857 & -26.42110 \\
\hline 2 & 2786.453 & 128.2976 & $1.24 \mathrm{e}-18 *$ & $-27.0440)^{*}$ & $-26.14332^{*}$ & $-26.67963 *$ \\
\hline 3 & 2809.458 & 42.36549 & $1.26 \mathrm{e}-18$ & -27.02433 & -25.71413 & -26.49422 \\
\hline 4 & 2828.257 & 33.69064 & $1.35 \mathrm{e}-18$ & -26.96294 & -25.24330 & -26.26717 \\
\hline 5 & 2850.113 & $38.08450 *$ & $1.39 \mathrm{e}-18$ & -26.93181 & -24.80272 & -26.07038 \\
\hline 6 & 2865.388 & 25.86223 & $1.54 \mathrm{e}-18$ & -26.83552 & -24.29700 & -25.80843 \\
\hline 7 & 2886.169 & 34.15564 & $1.62 \mathrm{e}-18$ & -26.79376 & -23.84580 & -25.60101 \\
\hline 8 & 2904.493 & 29.20838 & $1.75 \mathrm{e}-18$ & -26.72765 & -23.37025 & -25.36924 \\
\hline
\end{tabular}

Note: * indicates lag order selection by the criterion at $5 \%$ level. LR, FPE, AIC, SC and HQ stand for Likelihood Ratio, Final Prediction Error, Akaike Information Criterion, Schwarz Information Criterion and Hannan-Quinn Information Criterion, respectively. 
